\title{
Zonasi Konservasi untuk Siapa? Pengaturan Perairan Laut Taman Nasional Bali Barat
}

\author{
Amir Mahmud ${ }^{1}$ \\ Arif Satria, Rilus A. Kinseng ${ }^{2}$
}

\begin{abstract}
The zoning is not as usual and natural issues but complicated processes that determines allowed and prohibited activities of resources user. From economic views, zonation could potentially take advantages and disadvantages, and socially it create a conflict as consequence of limited accesses. This research as qualitative research aims to observe zones utilization and it impacts to marine resource users in Bali Barat National Parks (BBNP). The results show that utilization of marine zoning in BBNP is to ecology-biology protection, tourist and fisheries with resources user namely Boarding of BBNP, tourist company and fishers. Zoning results in regulating user activities including limited activities.
\end{abstract}

\section{Keywords:}

zones; marine of national park; tourist; fishers.

\begin{abstract}
Abstrak
Pembuatan zonasi bukanlah persoalan biasa dan alami melainkan proses yang rumit, yang menentukan diperbolehkan atau dilarangnya kegiatan para pengguna sumber daya alam. Secara ekonomi, zonasi dapat berpotensi mendatangkan keuntungan dan kerugian, dan secara sosial menimbulkan konflik akibat pembatasan akses. Penelitian ini menggunakan metode kualitatif untuk mengulas pemanfaatan zonasi dan akibatnya bagi pengguna sumber daya laut di Taman Nasional Bali Barat (TNBB). Hasilnya, pemanfaatan zonasi di laut TNBB dapat digunakan untuk perlindungan ekologi-biologi, pariwisata, dan perikanan dengan para pengguna yaitu Balai TNBB, perusahaan pariwisata dan nelayan. Zonasi berakibat pada pengaturan kegiatan para pengguna termasuk pembatasan.
\end{abstract}

\section{Kata Kunci:}

zonasi; perairan laut taman nasional; pariwisata; nelayan.

\section{Pendahuluan}

Pembentukan dan pengelolaan kawasan konservasi tidak hanya mempertimbangkan aspek ekologi-biologi tapi juga memperhatikan dimensi manusia dan sosiokulturalnya (Charles \&Wilson, 2009; Fiske, 1992; Sowman et al., 2011). Pengelolaan kawasan konservasi dianggap sukses dalam aspek ekologi tapi menemui

\footnotetext{
1 Peneliti di Sajogyo Institute (SAINS) Bogor, Peneliti berterima kasih kepada Ni Made Indrawati, pihak TNBB dan semua pihak yang telah membantu penelitian ini.

Email: mahmudamir1003@gmail.com.

2 Mahasiswa Program Studi Sosiologi Pedesaan, Departemen Sains Komunikasi dan Pengembangan Masyarakat, Fakultas Ekologi Manusia, Institut Pertanian Bogor
} 
kegagalan pada aspek sosial (Christie, 2004; Jennings, 2009). Pada aspek sosial dan ekonomi, salah satu dampak yang ditemukan pada nelayan adalah persoalan mata pencaharian (Bavinck \& Vivekanandan, 2011; Bennett \& Dearden, 2014; Oracion et al., 2005). Persoalanpersoalan muncul sebagian besar dimulai dari pemberlakuan kawasan konservasi beserta sistem zonasinya atau adanya zona larang ambil (no-take-zone) sehingga berdampak pada pembatasan untuk pemanfaatan sumber daya terhadap masyarakat.

Sebelum menjadi bagian dari Taman Nasional Bali Barat (TNBB,) perairan laut Bali Barat dan Pulau Menjangan serta laut sekitarnya rencananya akan dijadikan cagar alam laut (marine nature reserves) atau taman nasional laut (marine national park) (Polunin et al., 1983; Robinson et al., 1981). TNBB berdiri tahun 1984, meskipun penetapan secara definitif pada tahun 1995, berdasarkan Surat Keputusan Menteri Kehutanan No 493/KptsII/1995. Kawasan konservasi ini terbentang di dua kabupaten di Provinsi Bali yaitu Buleleng seluas $12.814,89$ ha dan Jembrana seluas $6.188,00$ ha. TNBB berasal dari gabungan kawasan suaka margasatwa dan hutan lindung yaitu Suaka Margasatwa Bali Barat, Suaka Margasatwa Pulau Menjangan dan sekitarnya (laut), dan Hutan Lindung Bali Barat. Kawasan konservasi TNBB memiliki luas 19.002,89 ha terdiri atas laut 3.415 ha dan daratan/hutan $15.587,89$ ha.

Taman nasional dikelola oleh pemerintah pusat berdasarkanUU5/1990, PP 68/1998 dan PP 28/2011. Pengelolaan TNBB dilakukan dengan pendekatan terpusat di bawah Kementerian Kehutanan (Kemenhut). Pendekatan terpusat dilakukan melalui pembentukan Balai Taman Nasional sebagai unit pelaksana teknis di tiap-tiap taman nasional di Indonesia. Sekalipun dikelola secara terpusat, peran pemerintah provinsi dan kabupaten/kota masih diperhatikan walaupun terbatas di dalam PP No. 28/2011, contohnya seperti konsultasi publik penyusunan rencana zonasi dan pemberdayaan masyarakat sekitar taman nasional. Masyarakat diikutsertakan pula dalam konsultasi publik untuk penyusunan rencana zonasi.

Tulisan ini membahas sistem zonasi yang diterapkan di TNBB khususnya di kawasan perairan laut. UU 5/1990 Pasal 32 menyebutkan bahwa kawasan taman nasional dikelola dengan sistem zonasi, dan menurut PP 68/1998 zonasi sebagai upaya pengawetan kawasan. Tiap zona dibedakan menurut fungsi dan kondisi ekologis, sosial, ekonomi dan budaya masyarakat (Permenhut P.56/2006). Akan tetapi, penerapan sistem zonasi memiliki dampak luar biasa terhadap masyarakat, misalnya akses (Ribot \& Peluso, 2003).

Secara historis, sebelum berdirinya TNBB, laut di sekitar taman nasional bersifat open access. Nelayan dari Bali maupun Jawa dapat memanfaatkan dan menangkap ikan di sekitar perairan laut, misalnya penangkapan bibit ikan bandeng (nyotok nener) di pesisir oleh nelayan. Namun pada tahun 1970-an diterbitkan pengaturan izin penangkapan oleh pemerintah daerah Provinsi Bali. Rezim open access kemudian berubah menjadi rezim state property, terutama ketika pemerintah mengatur pesisir dan laut melalui penerbitan izin penangkapanbibitikan bandeng dan penertiban pengkavlingan lokasi penangkapannya, dan ketika laut menjadi bagian dari taman nasional. Pembentukan taman nasional berakibat langsung terutama pada pembatasan akses nelayan di kawasan konservasi, kecuali mendapatkan izin atau masuk dalam sistem zonasi yang diperuntukkan bagi nelayan.

\section{Metode Penelitian}

Penelitian ini bertujuan mengetahui lebih dalam tentang pemanfaatan zonasi dan perubahannya, terutama zonasi perairan laut TNBB serta dampak penerapan zonasi terhadap aktivitas masyarakat. Demi mencapai tujuan tersebut, data yang dikumpulkan 
berupa data primer dan sekunder. Data primer diperoleh dari informan melalui teknik wawancara mendalam dengan alat bantu pedoman wawancara. Wawancara berlangsung secara tatap-mukadengan informan seperti nelayan, pihak TNBB, tokoh masyarakat desa Pakraman/Adat dan desa Dinas, Lembaga Swadaya Masyarakat dan lain sebagainya. Untuk memperkaya data, selain diskusi kelompok dengan pihak Balai TNBB, juga dilakukan pengamatan terlibat terhadap perairan laut TNBB untuk melihat seperti garis batas zonasi dan pemanfaatannya. Sementara data sekunder didapatkan dari kantor Balai TNBB, kantor desa (Sumber klampok dan Pejarakan) dan desa Adat/Pakraman, Dinas Perikanan dan Kelautan Kabupaten Buleleng, Balai Besar Riset Perikanan Budidaya Laut Gondol, perusahaan pariwisata, Kelompok Nelayan, Kelompok Masyarakat Pengawas (Pokmaswas), Forum Komunikasi Masyarakat Peduli Pesisir (FKMPP) dan LSM Pilang. Datadata sekunder lain berbentuk laporan, arsip, buku, tesis, jurnal, website dan data lainnya yang relevan dengan fokus penelitian.

Data-data penelitian dianalisis melalui tahapan pengumpulan data, analisis data, reduksi data, penyajian data, dan penarikan kesimpulan, yang berlangsung terus menerus dan dilakukan sejak perencanaan penelitian, tahap di lapangan sampai pembuatan laporan penelitian. Pemeriksaan keabsahan data menggunakan triangulasi di dalam pengumpulan data dan informan. Dalam mengulas zonasi, sangat penting pengumpulan data berupa peta zonasi dan perubahannya sekalipun peta tersebut tidak lengkap. Peta zonasi dan pemanfaatannya selanjutnya menjadi semacam panduan untuk dicocokkan dengan kondisi, kejadian dan aktivitas di lapangan.

Penelitian dilakukan di perairan laut Taman Nasional Bali Barat terutama di Desa Sumberklampok dan Desa Pejarakan Kecamatan Gerokgak Kabupaten Buleleng
Provinsi Bali. Lokasi ini sengaja dipilih dengan beberapa alasan yaitu a) Masing-masing desa merupakan desa enclave dan desa penyangga di TNBB; b) TNBB ditetapkan berdasarkan Keputusan Menteri Kehutanan No. 493/KptsII/1995. TNBB terdiri atas laut dan darat/hutan yang dikelola melalui zonasi, sistem zonasi tersebut mengalami tiga kali perubahan; c) Berkembangnya pariwisata di kawasan TNBB, terutama perairan laut, dan terdapat aktivitas perikanan tradisional skala kecil, di dua desa, khususnya di Teluk Terima (Sumberklampok) dan Teluk Banyuwedang (Pejarakan). Penelitian dilaksanakan pada bulan Februari sampai dengan awal Maret 2013, dan pertengahan Juni hingga akhir Juli 2013.

Zonasi atau zona merupakan istilah yang umum disebut, terutama dalam PP 68/1998, PP 28/2011 dan Permenhut No. P.56/ Menhut-II/2006. Kedua istilah dibuat dalam rangka pengelolaan dan pemanfaatan kawasan konservasi taman nasional. Keduanya memiliki arti berbeda berdasarkan Permenhut No. P.56/ Menhut-II/2006. Zonasi merupakan suatu proses pengaturan ruang dalam taman nasional menjadi zona-zona, yang mencakup kegiatan tahap persiapan, pengumpulan dan analisis data, penyusunan draft rancangan zonasi, konsultasi publik, perancangan, tata batas, dan penetapan, dengan mempertimbangkan kajian dari aspek ekologis, sosial, ekonomi dan budaya masyarakat. Wilayah di dalam kawasan taman nasional, yang dibedakan menurut fungsi dan kondisi ekologis, sosial, ekonomi dan budaya masyarakat disebut sebagai zona. Taman nasional minimal mempunyai tiga zona yaitu inti, rimba, dan pemanfaatan.

Keberadaan zonasi taman nasional berakibat pada akses, terutama masyarakat sekitar, berupa pembatasan, larangan atau kegiatan yang hanya diperbolehkan jika telah memperoleh izin. Akses dimaknai Ribot \& Peluso (2003: 154) sebagai "kemampuan untuk memperoleh manfaat dari sesuatu". Mekanisme akses, menurut Ribot \& Peluso 
(2003) terbagi dua yaitu: hak/aturan legal, serta struktural dan relasional. Mekanisme akses yang pertama berdasarkan hukum, kebiasaan atau konvensi termasuk illegal access, sedangkan mekanisme akses yang kedua melalui teknologi, modal, pasar, pekerjaan, pengetahuan, kewenangan, identitas sosial, negosiasi dari relasi sosial. Dengan begitu, pembuatan zonasi serta pembagiannya tidak hanya menentukan pemanfaatan kawasan, tapi berakibat pada akses para pengguna, baik kegiatan yang dilarang maupun tidak.

Proses zonasi menyerupai istilah yang digunakan Vandergeest (1995) dan Vandergeest \& Peluso (1996) yaitu teritorialisasi. Teritorialisasi didefinisikan Vandergeest sebagai proses yang dibuat negara untuk mengontrol orang dan tindakannya dengan menarik batas di sekeliling suatu ruang geografis, yang melarang beberapa kategori orang untuk masuk ke dalam ruang tersebut, dan memperbolehkan atau melarang kegiatan-kegiatan tertentu dalam batas tersebut. Teritorialisasi dibagi tiga tahap (Vandergeest, 1995; Vandergeest \& Peluso, 1996) yaitu:(1)Menegaskan kedaulatan teritorial dan kontrol hasil dengan menegaskan bahwa semua tanah "tak bertuan" atau "bukan milik siapa-siapa" adalah milik negara. (2) Pembuatan batas demarkasi wilayah yang jelas seperti antara "kawasan hutan" dan nonhutan. (3) "Teritorialisasi fungsional” dengan pembagian berbagai fungsi kawasan berdasarkan kriteria ilmiah seperti hutan produksi, hutan lindung dan cagar alam. Dalam konteks taman nasional, zonasi dan pembagiannya dibentuk dengan mengacu pada fungsi tiap zona, seperti inti, rimba dan pemanfaatan, berdasarkan kriteria ilmiah seperti kajian ekologi. Pembagian zona menurut fungsinya bertujuan mengatur kegiatan pemanfaatan yang dilarang dan yang diperbolehkan.

\section{Sistem Zonasi TNBB dan Perubahannya}

Dari segi potensi biologi, TNBB mempunyai potensi kekayaan fauna dan flora. Berdasarkan jenisnya, fauna di TNBB terdiri atas 7 jenis mamalia, 2 jenis reptilia, 105 jenis aves, 120 jenis ikan, dan lain-lain. Jenisjenis fauna yang dilindungi di TNBB antara lain: Trenggiling, Kesih (Bali) (Manis javanica), Jelarang, Kapan-kapan (Bali) (Ratufa bicolor), Landak (Hystrix brachyura), Kueuk (Felis marmorata), Menjangan (Cervus timorensis), Banteng (Bos javanicus), Pelanduk, Kancil (Bali) (Tragulus javanicus), Biawak (Varanus salvator), Penyu rider (Lepidochelys olivceae), dan Jalak Bali (Leucopsar rothschildi) (Pengembangan Pariwisata Alam di TNBB, 2005). TNBB pun sering diidentikkan dengan perlindungan bagi kelangsungan hidup atau keberadaan Jalak Bali.

Flora di TNBB terdiri atas dua ekosistem, yaitu tipe ekosistem darat seperti hutan mangrove, hutan pantai, hutan musim, hutan hujan dataran rendah, evergreen, savanna, river rain forest dan tipe ekosistem laut seperti terumbu karang, padang lamun, pantai berpasir, perairan laut dangkal dan perairan laut dalam. Jenis flora yang dilindungi di TNBB antara lain: Bayur (Pterospermum diversifolium), Buni (Antidesma bunius), Bungun (Lagerstroemia speciosa), Burahol (Stelechocarpus burahol), Cendana (Santalum album), Kemiri (Aleurites moluccana), Kepah, Kepuh (Bali) (Sterculia foetida), Kesambi (Schleichera oleosa), Kruing bunga (Diptercocaus hasseltii), Mundu (Garcinia dulcis), Pulai (Alstonia scholaris), Sawo kecik (Manilkara kauki), Sono kering (Dalbergia latifolia) dan Trengguli (Cassia fistula) (TNBB, 2005). Aneka jenis flora tersebut berada di lahan TNBB seluas 19.002,89 ha. Melimpahnya potensi biologi dan luasan kawasan tersebut menjadi salah satu alasan dibentuknya TNBB, demi melindungi keasliannya.

Disamping potensi biologi, ada beberapa desa yang berbatasan dengan TNBB, terdapat pula desa enclave (daerah kantong). Desa/ kelurahan penyangga di Kecamatan Melaya Kabupaten Jembrana terdiri atas Gilimanuk, Blimbingsari, Ekasari dan Melaya. Di Kecamatan Gerokgak Kabupaten Buleleng, 
Pejarakan adalah desa penyangga sedangkan desa enclanve-nya adalah Sumberklampok yang berada di dalam TNBB. Nelayan skala kecil di sebagian desa mata pencahariannya bergantung pada perairan laut TNBB. Namun demikian, potensi biologi dan kawasan TNBB ini pemanfaatannya diatur agar tidak menggangu atau merusak tujuan utama konservasi.

Secara umum pengelolaan dan pemanfaatan kawasan konservasi, termasuk

Tabel 1.

Fungsi Zona di Taman Nasional

\begin{tabular}{lll}
\hline Zona & \multicolumn{1}{c}{ Fungsi } & Kegiatan yang dapat dilakukan \\
\hline Inti & perlindunganekosistem, pengawetanflora & Perlindungan dan pengamanan; Inventarisasi dan \\
& dan fauna khas beserta habitatnya yang & monitoring sumber daya alam hayati dengan ekosistemnya; \\
& peka terhadap gangguan dan perubahan, Penelitian dan pengembangan, ilmu pengetahuan, \\
& sumberplasmanutfahdarijenistumbuhan pendidikan, dan atau penunjang budidaya; Dapat \\
& dan satwa liar, untuk kepentingan dibangun sarana dan prasarana tidak permanen, terbatas \\
& penelitian dan pengembangan ilmu untuk kegiatan penelitian dan pengelolaan. \\
& pengetahuan, pendidikan, penunjang \\
& budidaya.
\end{tabular}

Rimba/ perlin- kegiatan pengawetan dan pemanfaatan Perlindungan dan pengamanan; lnventarisasi dan dungan bahari sumber daya alam dan lingkungan alam monitoring sumber daya alam hayati dengan ekosistemnya; bagi kepentingan penelitian, pendidikan Pengembangan penelitian, pendidikan, wisata alam konservasi, wisata terbatas, habitat satwa terbatas, pemanfaatan jasa lingkungan dan kegiatan migran dan menunjang budidaya serta penunjang budidaya; Pembinaan habitat dan populasi mendukung zona inti. dalam rangka meningkatkan keberadaan populasi hidupan liar; Pembangunan sarana dan prasarana sepanjang masih dalam kepentingan penelitian, pendidikan, dan wisata alam terbatas.

Pemanfaatan pengembangan pariwisata alam dan Perlindungan dan pengamanan; Inventarisasi rekreasi, jasa lingkungan, pendidikan, dan monitoring sumber daya alam hayati dengan penelitian dan pengembangan yang ekosistemnya; Penelitian dan pengembangan pendidikan, menunjang pemanfaatan, dan kegiatan serta penunjang budidaya; Pengembangan potensi dan penunjang budidaya. daya tarik wisata alam; Pembinaan habitat dan populasi; Pengusahaan pariwisata alam dan pemanfatan kondisi/ jasa lingkungan; Pembangunan sarana dan prasarana pengelolaan, penelitian, pendidikan, wisata alam dan pemanfatan kondisi/jasa Iingkungan.

Tradisional pemanfaatan potensi tertentu taman Perlindungan dan pengamanan; Inventarisasi dan nasional oleh masyarakat setempat secara monitoring potensi jenis yang dimanfaatkan oleh lestari, melalui pengaturan pemanfaatan masyarakat; Pembinaan habitat dan populasi; Penelitian dalam rangka memenuhi kebutuhan dan pengembangan; Pemanfaatan potensi dan kondisi hidupnya. sumber daya alam sesuai dengan kesepakatan dan ketentuan yang berlaku.

Religi, budaya memperlihatkan dan melindungi Perlindungan dan pengamanan; Pemanfaatan pariwisata dan sejarah nilai-nilai hasiI karya, budaya, sejarah, alam, penelitian, pendidikan dan religi; Penyelenggaraan arkeologi maupun keagamaan, sebagai upacara adat; Pemeliharaan situs budaya dan sejarah, wahana penelitian; pendidikan dan serta keberlangsungan upacara-upacara ritual wisata alam sejarah, arkeologi, dan keagamaan/adat yang ada religius

Khusus kepentingan aktivitas kelompok Perlindungan dan pengamanan; Pemanfaatan untuk masyarakat yang tinggal di wilayah menunjang kehidupan masyarakat, rehabilitasi dan tersebut sebelum ditunjuk dan monitoring populasi dan aktivitas masyarakat, serta daya ditetapkan sebagai taman nasional dan dukung wilayah

sarana penunjang kehidupannya, serta kepentingan yang tidak dapat dihindari berupa sarana telekomunikasi, fasilitas transportasi dan Iistrik

Sumber: Peraturan Menteri Kehutanan No.: P. 56 /Menhut-II/2006 tentang Pedoman Zonasi Taman Nasional 
taman nasional, merujuk pada UU 5/1990, PP 28/2011 dan PP 68/1998. Dalam konteks taman nasional, dua peraturan pemerintah sebagai peraturan turunan dari UU 5/1990 menjadi pedoman dalam pengelolaan dan pemanfaatan, misalnya tujuan, kriteria kawasan dan penyelenggaraannya. Sementara Permenhut No. P.56/Menhut-II/2006 penting diuraikan untuk menganalisis pembuatan zonasi dan pembagian zona. Berdasarkan PP 28/2011 taman nasional bertujuan: (1) Penelitian dan pengembangan ilmu pengetahuan; (2) Pendidikan dan peningkatan kesadartahuan konservasi alam; (3) Penyimpanan dan/atau penyerapan karbon, pemanfaatan air serta energi air, panas, dan angin serta wisata alam; (4) Pemanfaatan tumbuhan dan satwa liar; (5) Pemanfaatan sumber plasma nutfah untuk penunjang budidaya; dan (6) Pemanfaatan tradisional oleh masyarakat setempat.

Tujuan pemanfaatan dalam PP tersebut diatur lagi secara rinci melalui kegiatankegiatan pemanfaatan dan sistem zonasi. Kawasan taman nasional dikelola dengan sistem zonasi sehingga beberapa kegiatannya, disesuaikan dengan pembagian zonasi, seperti diatur dalam PP 68/1998. Penerapan sistem zonasi ini membedakan taman nasional dengan kawasan konservasi lainnya yaitu cagar alam dan taman hutan raya. Berdasarkan Permenhut No. P.56/Menhut-II/2006, kegiatan yang diperbolehkan di zona-zona taman nasional adalah sebagai berikut:

Demi mengontrol kegiatan pemanfaatan agar tidak destruktif, dibutuhkan sistem zonasi di TNBB. Zonasi di kawasan konservasi TNBB dibuat pertama kali pada tahun 1987, dan selanjutnya berubah berturut-turut dengan zonasi 1996, zonasi 1999 dan zonasi 2010. Perubahan zonasi merupakan proses yang dijamin dalam peraturan, melalui sebuah evaluasi zonasi yang dilakukan secara periodik yaitu paling lama 3 tahun, jika merujuk pada Permenhut No P.56/Menhut-II/2006. Terjadinya tiga kali perubahan zonasi TNBB perlu dilihat dari masing-masing peristiwa yang melatarbelakangi dan zonasi baru yang dihasilkan daripada zonasi sebelumnya.

\section{Zonasi 1987}

Dua tahun setelah dicalonkan menjadi taman nasional pada Kongres Taman Nasional Sedunia yang ke III di Bali, TNBB akhirnya berdiri pada tahun 1984 dengan penetapan organisasi, tata kerja, dan wilayah kerjanya. Tiga tahun kemudian kawasan TNBB seluas 77.727 ha dibuat mintakat atau zonasi tahun 1987. Zonasi pertama yang dibuat ini mempunyai empat zona yaitu inti, rimba, pemanfaatan, dan penyangga.

\section{Tabel 2.}

\section{Mintakat atau Zonasi TNBB Tahun 1987}

\begin{tabular}{ll}
\hline Mintakat 1987 & Luas (77.727 ha) \\
\hline Inti & Darat: 40.650 ha. Laut: 3.670 ha \\
Rimba & 25.732 ha. \\
Pemanfaatan & Darat: 1.125 ha. Laut: 850 ha \\
Penyangga & Darat: 4.000 ha. Laut: 1.700 ha \\
\hline
\end{tabular}

Sumber: SK Dirjen PHPA No. 49/Kpts/DJVI/1987

Kawasan TNBB seluas 77.727 ha ini terdiri atas darat/hutan 71.507 ha dan laut 6.220 ha. Munculnya sistem zonasi di kawasan konservasi TNBB khususnya di perairan laut, mengakibatkan kegiatan penangkapan ikan konsumsi, ikan hias, dan pengambilan terumbu karang menjadi dilarang, kecuali telah mendapatkan izin dari taman nasional seperti penangkapan bibit ikan bandeng. Izin penangkapan bibit ikan bandeng pernah diterbitkan oleh Balai TNBB sekalipun tidak berjalan lama.

\section{Zonasi 1996}

Luas kawasan TNBB menyusut, yang awalnya seluas 77.727 ha menjadi $19.002,89$ ha karena perubahan fungsi kawasan pada tahun 1995, berdasarkan Keputusan Menteri Kehutanan No 493/Kpts-II/1995. Keputusan tersebut membuat hutan lindung (265,30 ha), suaka margasatwa $(15.322,59$ ha) dan perairan 
sekitarnya (3.415 ha) menjadi kawasan TNBB. Perubahan fungsi kawasan sekaligus menuntut perubahan zonasi sehingga muncullah zonasi 1996.

Tabel 3. Zonasi TNBB Tahun 1996

\begin{tabular}{ll}
\hline Zonasi 1996 & Luas $(19.002,89$ ha) \\
\hline Inti & Total (darat dan laut 970,00 ha \\
Rimba & Darat: $6.281,00$ ha., Laut: 515,00 ha \\
Pemanfaatan & Darat: $1.613,00$ ha., Laut: $1.960,00$ ha \\
\hline
\end{tabular}

Sumber: SK Dirjen PHPA No. 38/Kpts/DJVI/1996

Kawasan TNBB seluas 19.002,89 ha dibagi menjadi tiga zona yaitu inti, rimba, dan pemanfaatan. Perbedaan signifikan antara zonasi 1996 dengan zonasi sebelumnya terletak pada penyusutan luas kawasan darat/hutan dan laut, serta berkurangnya jumlah zona dari empat zona menjadi tiga zona (tanpa zona penyangga). Pada zonasi 1987 luas darat/ hutan 71.507 ha dan laut 6.220 ha sedangkan zonasi 1996 luas $15.587,89$ ha dan laut 3.415 ha. Dengan penyusutan luas kawasan TNBB ini dapat memudahkan dalam memaksimalkan pengelolaan TNBB.

\section{Zonasi 1999}

Zonasi tahun 1999 terdiri atas empat zona yaitu inti, rimba, pemanfaatan intensif dan pemanfaatan budaya. Keempat zona dan luasannya sebagai berikut:
Tabel 4. Zonasi TNBB Tahun 1999

\begin{tabular}{ll}
\hline Zonasi 1999 & Luas $(19.002,89$ ha) \\
\hline Inti & Darat: $7.567,85$ ha., Laut: \pm \\
& 455,37 ha \\
Rimba & Darat: $\pm 6.099,46$ ha., Laut: \\
& 243,96 ha \\
Pemanfaatan Intensif & Darat: $\pm 1.645,33$ ha., Laut: \pm \\
& $2.745,66$ ha \\
Pemanfaatan Budaya & Darat: 245,26 ha \\
\hline
\end{tabular}

Sumber: Keputusan Dirjen PKA No. 186/Kpts/ DJ-V/1999

Perbedaan zonasi tahun 1999 dengan zonasi sebelumnya terletak pada munculnya zona pemanfaatan intensif dan zona pemanfaatan budaya. Di samping itu, luasan masing-masing zona dengan zona sebelumnya tidak sama. Salah satu penyebab munculnya zona pemanfaatan intensif adalah makin intensifnya pengembangan pariwisata dengan masuknya perusahaan yang bergerak di bidang pariwisata dalam kurun 1997-2003. Lokasi perusahaan ini terlihat jelas dalam peta zonasi 1999. Tiga perusahaan di bidang pariwisata mendapatkan Izin Pemanfaatan Pariwisata Alam (IPPA) di TNBB. Ketiga perusahaan itu dapat dilihat pada Tabel 5.

Perusahaan pariwisata mendirikan bangunan seperti hotel/resort atau kantor, sebagian besar didirikan berdekatan dengan pantai. Melalui perusahaan tersebut, sarana pengembangan pariwisata diharapkan semakin

Tabel 5.

Tiga Perusahaan di TNBB

\begin{tabular}{|c|c|c|c|}
\hline No & $\begin{array}{l}\text { Perusahaan } \\
\text { pengelola/ } \\
\text { pelaksana }\end{array}$ & Jenis usaha/ kegiatan wisata yang dikembangkan & Lokasi dan luas \\
\hline 1 & SBW & $\begin{array}{l}\text { Pengusahaan Pariwisata Alam (Resort): Wisata bahari } \\
\text { (diving, snorkeling, canoing), bird watching dan jungle } \\
\text { tracking }\end{array}$ & $\begin{array}{l}\text { Labuhan Lalang, Tanjung Kotal, dan } \\
\text { Gilimanuk. } \\
\text { Luas 251,5 Ha }\end{array}$ \\
\hline 2 & TSS & $\begin{array}{l}\text { Pengusahaan Pariwisata Alam (Resort): Wisata bahari } \\
\text { (diving, snorkeling, canoing), bird watching, jungle } \\
\text { tracking dan wisata berkuda }\end{array}$ & $\begin{array}{l}\text { Tanjung Gelap dan Banyuwedang. } \\
\text { Luas } 284 \mathrm{Ha}\end{array}$ \\
\hline 3 & DKB & $\begin{array}{l}\text { Pengusahaan Pariwisata Alam (Budidaya Mutiara): } \\
\text { Wisata bahari dengan minat khusus seperti tiram } \\
\text { mutiara) }\end{array}$ & $\begin{array}{l}\text { Teluk Terima, Tanjung Kotal dan } \\
\text { Cekik. } \\
\text { Luas } 40,05 \mathrm{Ha}\end{array}$ \\
\hline
\end{tabular}

Sumber: Pengembangan Pariwisata Alam di TNBB (2005) dan dari sumber lain. 
meningkat dan potensi pariwisata dapat dimanfaatkan secara intensif di kawasan konservasi. Sedangkan keberadaan zona pemanfaatan budaya dalam zonasi 1999 dikarenakan adanya kegiatan spiritualkeagamaan penganut Hindu di pura yang terletak di kawasan TNBB. Kegiatan spiritualkeagamaan ini telah dilakukan dari sebelum kawasan konservasi dibuat sehingga perlu diakomodasi dalam sistem zonasi. Terlebih lagi adanya Perda Provinsi Bali No 3/2005 tentang Rencana Tata Ruang Wilayah Prov. Bali, dan keputusan Parisada Hindu Dharma Indonesia (PHDI) Pusat No. 11/Kep.///PHDI/1994 tentang Bihisma Kesucian Pura.

\section{Zonasi 2010}

Pada tahun 2010 TNBB menetapkan tujuh zona yaitu zona inti, rimba, perlindungan bahari, pemanfaatan, budaya, religi dan sejarah, khusus, dan zona tradisional. Hal menarik dari ketujuh zona ini adalah munculnya zona tradisional di perairan laut. Zona ini diperuntukkan bagi kegiatan penangkapan ikan konsumsi oleh nelayan tradisional.

Untuk menampung kebutuhan nelayan, maka dibentuk zona tradisional di dua lokasi yaitu Teluk Terima $( \pm 51,905$ ha) dan Teluk Gilimanuk ( $\pm 259,038$ ha). Sebelum adanya zonasi 2010, kegiatan di perairan laut kawasan konservasi TNBB dilarang, contohnya penangkapan ikan konsumsi dan pengembangan budidaya seperti rumput laut dan ikan kerapu oleh masyarakat setempat.
Pembatasan akses nelayan tradisional terhadap sumber daya laut ini menimbulkan konflik antara nelayan dengan Balai TNBB. Konflik juga terjadi antara pengelola pariwisata dengan nelayan dalam pemanfaatan perairan laut.

Merujuk pada Gambar 1, zona tradisional berwarna coklat. Masing-masing zona memiliki warna berbeda yaitu: merah (zona inti), kuning (zona rimba), biru tua (zona perlindungan bahari), hijau (zona pemanfaatan), ungu tua (zona religi budaya dan sejarah), dan abu-abu tua (zona khusus).

Sistem zonasi yang diterapkan di sebuah taman nasional memiliki batasan antarzona yang jelas, tujuannya agar potensi dan fungsi masing-masing zona tetap terpelihara dengan baik. Misalnya, tanda batas di wilayan daratan ditandai dengan plat seng, papan kayu atau bahan lain sedangkan tanda mooring buoys untuk menandai batas antarzona di perairan laut.

Setiap zona baik di daratan maupun di perairan laut memiliki warna dan kode pada tanda batas sesuai dengan zonanya. Di kawasan konservasi TNBB khususnya perairan laut, tanda batas di lapangan tidak tersedia, sekalipun garis batas antarzonasi terdapat jelas secara imajiner dalam peta. Ketiadaan batas ini menyulitkan para pengguna dalam menentukan batas antarzonasi untuk kegiatan pemanfaatan perairan laut karena antara wilayah yang dilarang dan diperbolehkan menjadi kabur. Konsekuensinya, dapat menghambat upaya perlindungan kawasan

Tabel 6.

Zonasi TNBB Tahun 2010

\begin{tabular}{ll}
\hline Zonasi 2010 & Luas $(19.002,89$ ha $)$ \\
\hline Inti & Darat: $\pm 7.567,850$ ha., Laut: $\pm 455,370$ ha. \\
Rimba & $\pm 6.174,756$ ha \\
Perlindungan Bahari & $\pm 221,741$ ha \\
Pemanfaatan & Darat: $\pm 1.800,682$ ha., Laut: $\pm 2.417,011$ ha \\
Budaya Religi dan Sejarah & $\pm 50,570$ ha \\
Khusus & $\pm 3,967$ ha \\
Tradisional & $\pm 310,943$ \\
\hline
\end{tabular}

Sumber: Keputusan Dirjen PHKA No. SK. 143/ VI-KK/2010 


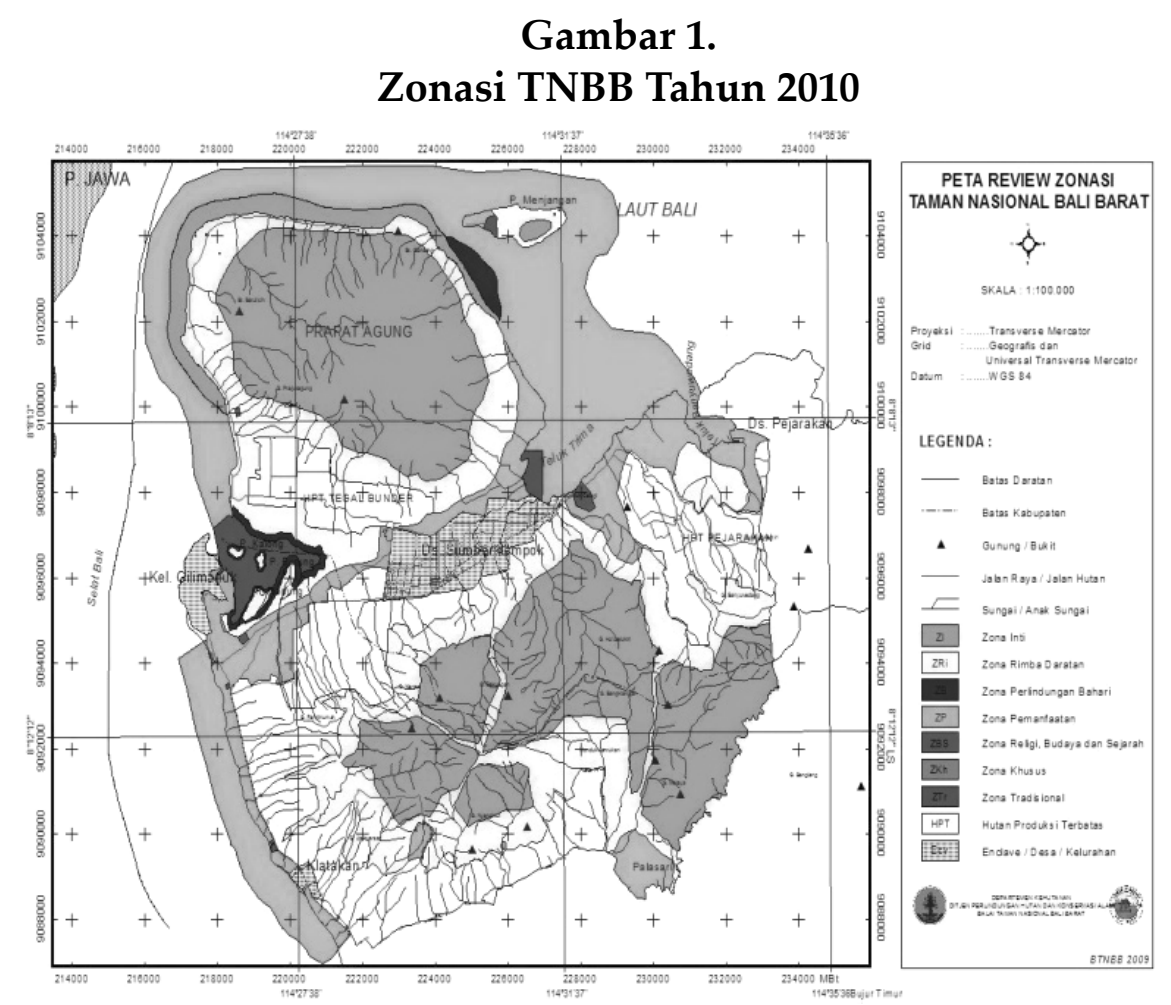

Sumber: Balai TNBB

Tabel 7.

Zonasi dan Kode/Inisial

\begin{tabular}{cll}
\hline No & Nama zonasi daratan dan kode/inisial & Nama zonasi perairan laut dan kode/inisial \\
\hline 1 & Inti = ZI & Inti = ZI \\
2 & Rimba = Zri & Perlindungan Bahari = ZB \\
3 & Pemanfaatan = ZP & Pemanfaatan = ZB \\
4 & Tradisional = ZTr & Tradisional = ZTr \\
5 & Rehabilitasi = Zre & Khusus = ZKh \\
6 & Religi, Budaya dan Sejarah = ZBS & Rehabilitasi = Zre \\
7 & Khusus = ZKh & Religi, Budaya dan Sejarah = ZBS \\
\hline
\end{tabular}

Sumber: Permenhut No. P. 56/Menhut-II/2006

konservasi secara keseluruhan; potensi pelanggaran oleh pengguna seperti nelayan dan wisatawan; dan sulitnya petugas dalam menegakkan aturan. Kondisi ini menegaskan bahwa kinerja pengelolaan kelembagaan TNBB di laut dinilai masih rapuh (failure).

Di kawasan konservasi TNBB terdapat para pengguna seperti nelayan dan wisatawan, yang memanfaatkan potensi sumberdaya alam terutama perairan laut, sehingga dibuatlah aturan yang lebih terperinci selain berdasarkan sistem zonasi yang diterapkan. Aturan bersifat teknis dan terperinci ini mengatur kegiatan yang dilarang beserta sanksi yang diberlakukan. Jenis pelanggaran dan sanksinya dapat dilihat pada Tabel 8.

Aturan ini diterapkan dengan konsisten dalam setiap kegiatan patroli. Misalnya, Laporan Tahunan Kegiatan Penyidikan dan Perlindungan Hutan TNBB 2011 dan 2012 menyebutkan bahwa 1 orang ditemukan menangkap ikan hias dengan menggunakan cairan potasium pada tahun 2011, divonis 4 bulan penjara dan denda Rp 300.000, dengan ketentuan apabila denda tidak dibayar maka diganti dengan hukum kurungan selama 
Tabel 8.

Jenis Pelanggaran dan Sanksi

\begin{tabular}{|c|c|}
\hline Jenis Pelanggaran & Jenis Sanksi \\
\hline $\begin{array}{l}\text { Memberi makan ikan oleh pelaku wisata; } \\
\text { Membuang sampah sembarangan maupun limbah } \\
\text { domestik; } \\
\text { Menjaring ikan konsumsi di atas karang. }\end{array}$ & $\begin{array}{l}\text { Pengarahan, pembinaan dan pembuatan surat } \\
\text { pernyataan; }\end{array}$ \\
\hline $\begin{array}{l}\text { Menaruh jangkar di atas karang untuk menambatkan } \\
\text { perahu; } \\
\text { Mencari ikan hias; } \\
\text { Mencari ikan dengan menggunakan panah (speargun). }\end{array}$ & $\begin{array}{l}\text { Penahanan untuk sementara, pembuatan surat } \\
\text { pernyataan, serta menjalani wajib lapor selama } \\
\text { minimal satu minggu semenjak tertangkap tangan; }\end{array}$ \\
\hline $\begin{array}{l}\text { Penggunaan racun seperti potasium untuk mencari ikan; } \\
\text { Menangkap ikan secara destruktif, contohnya } \\
\text { menggunakan dinamit atau bom. }\end{array}$ & $\begin{array}{l}\text { Pidana penjara selama-lamanya antara 6-10 tahun dan } \\
\text { atau denda paling banyak antara Rp 1,2 M-Rp } 2 \mathrm{M} \text {. }\end{array}$ \\
\hline
\end{tabular}

Sumber: Petunjuk Teknis Penanganan Terpadu Tindak Pidana Kehutanan dan Perairan TNBB (2005)

1 bulan. Sementara tahun 2012, 14 orang terbukti mencari dan menangkap biota laut seperti gurita, ikan hias dan karang hidup, dan dikenakan sanksi. Seiring perkembangan pariwisata perairan laut, aturan baru dibuat seperti tertuang dalam Code of Conduct berdasarkan SK Kepala Balai TNBB No. 513/ IV-BTNBB/2002 tanggal 29 April 2002. Code of Conduct bertujuan untuk mengembangkan wisata alam dengan memanfaatkan kawasan perairan laut TNBB, khususnya perairan laut Pulau Menjangan dan sekitarnya. Butir-butir Code of Conduct sebagai berikut:

1. Dilarang membuang dan meninggalkan sampah serta bahan pencemar lain;

2. Dilarang berjalan di atas karang atau menyentuh karang;

3. Dilarang merusak dan mengambil biota laut;

4. Dilarang memancing ikan di areal penyelaman radius \pm 500 meter dari garis pantai Pulau Menjangan;

5. Dilarang memberi makan ikan;

6. Dilarang membuang jangkar;

7. Pastikan peralatan dengan baik.

Sanksi atas pelanggaran Code of Conduct ditentukan secara kolektif oleh pengelola TNBB dan para pihak pengguna, sanksi-sanksi tersebut adalah: 1) Para pihak yang ditemukan atau diindikasikanmelanggar CodeofConduct diberikan peringatan I, II, dan III; 2) Pelanggar yang telah memperoleh peringatan sampai tiga kali akan dihentikan pelayanan administrasinya; dan 3) Sanksi Code of Conduct tidak menghilangkann atau menghapus sanksi pelanggaran pidana. Pembahasan butir-butir tersebut dilaksanakan oleh para pihak pada lokakarya Friends of the Reef pada tanggal 5-7 Februari 2002 sedangkan sosialisasinya dilakukan di kantor TNBB pada 16 April 2002.

\section{Pembagian Zona Untuk Apa dan Siapa?}

Perubahan zonasi dapat dilakukan secara periodik, namun penataan zona taman nasional harus didasarkan pada potensi dan fungsi kawasan, dengan memerhatikan aspek ekologi, sosial, ekonomi dan budaya masyarakat seperti terurai dalam Permenhut No P.56 / Menhut-II/2006. Beberapa hal yang menjadi pertimbangan dalam menentukan potensi dan fungsi suatu kawasan konservasi diantaranya adalah keanekaragaman hayati, nilai arkeologi, nilai objek wisata dan nilai jasa lingkungan. Aspek ekologi yang diperhatikan seperti tanah, geologi, iklim, topografi, geomorfologi dan penggunaan lahan, serta oseanografi pada wilayah perairan. Begitu pula, tak kalah penting diperhatikan adalah aspek sosial, ekonomi dan budaya masyarakat seperti jumlah pengguna kawasan, mata pencaharian dan kearifan lokal 
Tabel 9.

Pemanfaatan Zonasi TNBB

\begin{tabular}{lcccc}
\hline \multicolumn{1}{c}{ Pemanfaatan } & Mintakat 1987 & Zonasi 1996 & Zonasi 1999 & Zonasi 2010 \\
\hline Perlindungan ekologi-biologi & $\mathrm{V}$ & $\mathrm{V}$ & $\mathrm{V}$ & $\mathrm{V}$ \\
Pariwisata & $\mathrm{V}$ & $\mathrm{V}$ & $\mathrm{V}$ & $\mathrm{V}$ \\
Budaya religi dan sejarah & $\mathrm{X}$ & $\mathrm{V}$ & $\mathrm{V}$ & $\mathrm{V}$ \\
Perikanan & $\mathrm{X}$ & $\mathrm{X}$ & $\mathrm{X}$ & $\mathrm{V}$ \\
\hline
\end{tabular}

Keterangan: $(v)$ tersedia, $(x)$ tidak tersedia

Sumber: Data diolah dari zonasi

sebelum dibentuknya kawasan taman nasional, agar pengelolaan mendapat dukungan dari masyarakat setempat.

Dari keempat zonasi yang pernah dibuat dan tiga kali perubahan, terdapat tiga hal menarik yang perlu diperhatikan dari perubahan tersebut. Tiga hal menarik tersebut muncul seiring dibuatnya zona pemanfaatan intensif, zona pemanfaatan budaya (dan zona budaya, religi, dan sejarah), dan zona tradisional.

Di kawasan TNBB, pemanfaatan pariwisata semakin meningkat ketika tiga perusahaan mendapatkan Izin Pemanfaatan Pariwisata Alam (IPPA). Masing-masing memiliki daerah pemanfaatan seluas 251,5 ha, 284 ha, dan 40,05 ha. Hal itu terlihat dari ketersediaan zona pemanfaatan intensif dalam zonasi 1999. Sebagian besar perusahaan ber-IPPA tersebut mendirikan bangunan berupa kantor dan resort/hotel di sekitar laut untuk menunjang kegiatan pariwisata. Mekanisme akses perusahaan ini melalui atura legal seperti dalam PP 36/2010 tentang Pengusahaan Pariwisata Alam. Sementara itu, keberadaan zona inti dan zona rimba (dan zona perlindungan bahari) memang selalu tersedia dalam tiap perubahan zonasi sebagai zona perlindungan utama sekalipun dari segi jumlah luas ketiga zona tersebut terkadang mengalami perubahan.

Zona pemanfaatan budaya dan zona budaya religi dan sejarah masing-masing disediakan pada zonasi tahun 1999 dan tahun 2010 untuk kegiatan ritual keagamaan penganut Hindu di Pura yang terletak di TNBB. Zonasi tersebut tidak ada pada tahun 1987 dan tahun 1996. Meski terkesan terlambat, ketersediaan zona ini adalah bentuk pengakuan sekaligus penghormatan terhadap sejarah, budaya dan keagamaan penganut Hindu, yang telah ada sebelum berdirinya TNBB. Hal tersebut salah satunya disebabkan karena di kawasan TNBB terdapat beberapa pura yang memiliki akar sejarah, budaya dan keagamaan bagi penganut Hindu. Sesuai dengan Permenhut No: P. 56 / Menhut-II/2006 Pasal 6, zona ini berfungsi untuk memperlihatkan dan melindungi nilainilai hasil karya, budaya, sejarah, arkeologi maupun keagamaan. Selain itu juga sebagai wahana penelitian, pendidikan dan wisata alam sejarah, serta arkeologi dan religius. Jika ditelusuri, mekanisme akses awalnya diperoleh oleh penganut Hindu melalui struktural dan relasional, yaitu identitas sosial dan negosiasi, kemudian memasuki mekanisme aturan legal karena tersedia dalam sistem zonasi.

Aktivitas nelayan tradisional diakomodasi pada zonasi tahun 2010 melalui zona tradisional. Letak zona ini berdekatan dengan Kelurahan Gilimanuk (Teluk Gilimanuk) dan Desa Sumberklampok (Teluk Terima). Zona tradisional merupakan akses sekaligus memberi manfaat bagi nelayan melalui mekanisme aturan legal, meski terkadang akses tersebut diperoleh dari mekanisme struktural dan relasional. Secara sosio-historis, nelayan tradisional telah beraktivitas sebelum TNBB dibentuk. Jalan negosiasi ditempuh untuk mendapatkan beberapa kelonggaran beraktivitas di wilayah yang tidak diizinkan seperti waktu tangkap, alat tangkap dan 
wilayah tangkap. Zona tradisional berfungsi untuk memanfaatkan potensi tertentu taman nasional oleh masyarakat setempat secara lestari, melalui pengaturan pemanfaatan dalam rangka memenuhi kebutuhan hidupnya, seperti yang tercantum di pasal 6 Permenhut No. P. 56/2006.

Ketiga perubahan zonasi di atas memperlihatkan bahwa masing-masing perubahan tidak terjadi dalam ruang hampa. Terdapat kepentingan yang menyertai seperti kebutuhan masyarakat atau pengembangan potensi kawasan konservasi, seperti yang terlihat jelas jika membandingkan zonasi awal dengan zonasi hasil perubahan. Misalnya, kebutuhan nelayan yang tidak muncul dalam sistem zonasi awal, baru diakomodasi di zonasi 2010, padahal nelayan tradisional telah ada jauh sebelum dibentuknya TNBB. Fakta ini menegaskan perlunya meningkatkan level keterlibatan para pihak yang berkepentingan, terutama masyarakat setempat, dalam pembuatan atau perubahan zonasi agar kebutuhannya terakomodasi.

Meski selama ini konsultasi publik telah diagendakan dalam tata cara penataan zonasi, namun keterlibatan masyarakat dibatasi hanya pada memberi saran, informasi dan pertimbangan, sebagaimana terurai dalam Permenhut No P.56/Menhut-II/2006. Keterlibatan yang lemah dalam pembuatan keputusan publik membuat masyarakat perlu didorong dan ditingkatkan partisipasinya. Sistem zonasi mengatur kegiatan yang diperbolehkan dan yang dilarang, sehingga akan berdampak baik positif maupun negatif pada kegiatan masyarakat.

Kenyataan ini mengungkapkan bahwa zonasi bukanhanya persoalan teknis-instrumental tapi juga politik (Satria, 2014). Perubahan sistem zonasi bukan proses yang berjalan biasa dan alami namun berkaitan dengan kehadiran para pihak yang memperjuangkan akses atau tipe hak kepemilikan terhadap sumber daya alam. Artinya, siapa saja yang diperbolehkan terlibat dan sejauh mana keterlibatannya dalam penataan atau evaluasi sistem zonasi, akan menentukan besar-kecilnya akses para pengguna dan jenis kegiatan yang diperbolehkan dan dilarang dalam kawasan konservasi.

Bagi pengguna sumber daya di TNBB seperti nelayan, ketiadaan zona tradisional berakibat pada larangan kegiatan penangkapan ikan di kawasan konservasi. Secara sosial, bersamaan dengan hadirnya kawasan konservasi, aktivitas penangkapan ikan tersingkir sehingga berdampak pada munculnya konflik sosial seperti pembakaran gubuk nelayan nyotok nener, pencabutan alat budidaya rumput laut dan larangan lainnya. Penghentian penangkapan ikan pun berpotensi merugikan mata pencaharian nelayan.

\section{Kesimpulan}

Merujuk pada konteks pengelolaannya, tujuan dibentuknya kawasan TNBB tak hanya sebagai upaya perlindungan ekologi-biologi. Dalam proses perkembangannya, pembentukan tersebut mendorong peningkatan pemanfaatan pariwisata dan tersedianya lokasi pemanfaatan perikanannelayan sertasejarahbudaya keagamaan penganut Hindu. Pemanfaatan pariwisata semakin tumbuh dengan hadirnya perusahaan yang bergerak di bidang pariwisata melalui IPPA. Pemanfaatan budaya diciptakan untuk mengakomodasi aktivitas ritual-keagamaan dan budaya penganut Hindu di pura, sedangkan perikanan disediakan sebagai mata pencaharian nelayan. Jika merujuk pada perencanaan kawasan ini, lokasi untuk konservasi di perairan laut Bali Barat diprediksi menghasilkan nilai ekonomi dari ekoturisme. Kegiatan pemanfaatan seperti tradisional use, wilderness, dan sanctuary di kawasan ini rencananya akan diatur, meskipun berpotensi menimbulkan konflik nelayan (Polunin et al., 1983; Robinson et al., 1981).

Berdasarkan studi kasus di atas, beberapa hal dapat dijadikan catatan penting. Pertama, berdasarkan IUCN (International Union for Conservation of Nature) kawasan perlindungan 
kategori II konservasi dan perlindungan ekosistem merujuk pada taman nasional, sekalipun pemakaian nama 'Taman Nasional' terkadang digunakan oleh pelbagai kategori, mulai kategori I-VI (Dudley, 2008: 11). Tujuan utama kategori II adalah melindungi keanekaragaman hayati dengan struktur ekologi yang mendasarinya, mendukung proses lingkungan, dan mempromosikan pendidikan dan rekreasi. Desain pengelolaan taman nasional juga diperlukan, misalnya dengan memasukkan tujuan sosial, budaya dan ekonomi masyarakat setempat.

Sebab, kawasan konservasi hanya akan berkelanjutan jika ada keseimbangan tujuan seperti meningkatkan mata pencaharian masyarakat lokal sekaligus melindungi ekosistem melalui pengurangan kemiskinan, peningkatan rehabilitasi, serta perlindungan budaya dan keanekaragaman hayati (Wang, 2012). Dalam tahap perkembangan pengelolaan TNBB selama kurang lebih 20 tahun, kebutuhan masyarakat relatif terakomodasi walau membutuhkan waktu lama. Misalnya, mengakomodasi nilai-nilai sejarah budaya keagamaan penganut Hindu seperti ritual keagamaan di pura, kebutuhan nelayan dan pemanfaatan ekoturisme.

Melihat perkembangan ini, Kalamandeen \& Gillson (2007) menyatakan bahwa sejarah pendekatan konservasi mengalami perubahan pemahaman, yaitu hubungan antara manusia dengan alam dan reintegrasi sistem ekologi dengan sistem sosial. Hubungan sistem ekologi dan sosial akan terpusat dalam pengembangan strategi konservasi, yaitu melalui rekonsiliasi kebutuhan sosial, budaya, dan ekonomi yang bertujuan konservasi dengan batasan intrinsik sistem ekologi. Artinya, kawasan konservasi tidak hanya fokus pada perlindungan biologiekologi, tapi juga pada kebutuhan manusia dalam pemanfaatannya seperti sosial, budaya dan ekonomi.

Kedua, zonasi bertujuan untuk mengatur kegiatan pemanfaatan agar daerah utama tidak terpengaruh (Agardy, 1993). Namun secara umum pembuatan zonasi bukanlah tugas yang sederhana (Day, 2002). Menentukan zonasi yang dapat diterima secara sosial terhadap zonasi larang ambil merupakan proses yang sulit (Grantham, 2013). Begitu pula dalam mengakomodasi kegiatan nelayan melalui zona tradisional, sehingga zonasi baru tersedia tahun 2010. Kesulitan tersebut diperkirakan karena pemerintah hanya fokus pada tujuan utama taman nasional, sehingga kegiatan perikanan yang relatif eksploitatif dianggap bertentangan dengan kaidah 'konservasi' dan nelayan yang terlibat pun jumlahnya minim.

Pembuatan dan perubahan zonasi berdampak pada boleh-tidaknya aktivitas tertentu dilaksanakan di kawasan konservasi, termasuk aktivitas perikanan oleh nelayan tradisional. Dengan begitu, sistem zonasi bukan hanya persoalan teknis-instrumental seperti membatasi luas wilayah laut yang ditandai mooring buoys, tapi secara sosial dan ekonomi berpotensi menimbulkan konflik dan mengurangi akses nelayan. Oleh karenanya diperlukan proses politik zonasi, yang harus melibatkan para pihak berkepentingan terutama masyarakat setempat, dengan level keterlibatan yang tinggi.

Ketiga, meningkatkan keterlibatan masyarakat setempat menjadi penting untuk dikedepankan, karena kesuksesan sebuah kawasan konservasi dapat dilihat dari pihakpihak yang terlibat dalam proses zonasi (Agardy, 1993; Day, 2002). Keterlibatan juga harus didorong dalam pengelolaan kawasan konservasi, supaya kepentingannya dapat diperjuangkan dan diakomodasi, sehingga tidak ada yang merasa dirugikan. Paling tidak, persoalan seperti memarjinalkan masyarakat setempat, konflik sosial, dan kerugian ekonomi karena dampak zonasi dapat diminimalisir. Kesimpulannya, zonasi di laut TNBB dimanfaatkan untuk perlindungan ekologi-biologi, pariwisata dan perikanan yang dilakukan oleh Balai TNBB, perusahaan pariwisata dan nelayan. Zonasi berdampak 
pada peluang akses para pihak, terutama masyarakat setempat, terhadap sumber daya di kawasan konservasi karena mengatur kegiatan yang dilarang maupun yang diizinkan. Pihakpihak tersebut perlu dilibatkan dalam proses zonasi melalui peningkatan level partisipasi masyarakat, tujuannya agar zonasi dapat dipahami dan dapat diterima. Keterlibatan masyarakat dalam pengelolaan kawasan konservasi seperti pengelolaan kolaboratif taman nasional juga harus mendapat perhatian serius.

\section{Daftar Pustaka}

Agardy, M.Tundi. (1993). Accommodating Ecotourism in Multiple Use Planning of Coastal and Marine Protected Areas. Ocean $\mathcal{E}$ Coastal Management 20, 219-239.

Bavinck, Maarten \& Vivekanandan, Vriddagiri. (2011). Conservation, Conflict and The Governance of Fisher Wellbeing: Analysis of The Establishment of The Gulf of Mannar National Park and Biosphere Reserve. Environmental Management, 47:593-602.

Bennett, Nathan James \& Dearden, Philip. (2014). Why Local People Do Not Support Conservation: Community Perceptions of Marine Protected Area Livelihood Impacts, Governance and Management in Thailand. Marine Policy, 44, 107-116.

Charles, Anthony \& Wilson, Lisette. (2009). Human Dimensions of Marine Protected Areas. ICES Journal of Marine Science, 66: 6- 15 .

Charnley, Susan. (2005). From Nature Tourism to Ecotourism? The Case of The Ngorongoro Conservation Area, Tanzania. Human Organization, vol. 64, No. 1.

Christie, Patrick. (2004). Marine Protected Areas as Biological Successes and Social Failures in Southeast Asia. American Fisheries Society Symposium 42:155-164.

Day, Jon C. (2002). Zoning - Lessons from The Great Barrier Reef Marine Park. Ocean $\mathcal{E}$ Coastal Management, Vol 45, 139 - 156.
Dudley, N. Ed/(2008). Guidelines for Applying Protected Area Management Categories. Gland, Switzerland: IUCN.

Fiske, Shirley J. (1992). Sociocultural Aspects of Estabfishing Marine Protected Areas. Ocean $\mathcal{E}$ Coastal Management, 18, 25-46.

Grantham, Hedley S.; Agostini, Vera N.; Wilson, Joanne; Mangubhai, Sangeeta; Hidayat, Nur; Muljadi, Andreas; Muhajir; Rotinsulu, Chris; Mongdong, Meity; Beck, Michael W., \& Possingham, Hugh P. (2013). A Comparision of Zoning Analyses to Inform The Planning of A Marine Protected Area Network in Raja Ampat, Indonesia. Marine Policy 38, 184-194.

Jennings, Simon. (2009). The Role of Marine Protected Areas in Environmental Management. ICES Journal of Marine Science, 66: $16-21$.

Kalamandeen, Michelle \& Gillson, Lindsey. (2007). Demything "Wilderness": Implications for Protected Area Designation and Management. Biodivers Conserv, 16:165-182.

Oracion, Enrique G.; Miller, Marc L.; \& Christie, Patrick. (2005). Marine Protected Areas for Whom? Fisheries, Tourism, and Solidarity in a Philippine Community. Ocean \& Coastal Management, 48, 393 - 410.

Peraturan Menteri Kehutanan (Permenhut) No. P.56/Menhut-II/2006 tentang Pedoman Zonasi Taman Nasional.

Peraturan Pemerintah (PP) No. 28/2011 tentang Pengelolaan Kawasan Suaka Alam dan Kawasan Pelestarian Alam.

Peraturan Pemerintah (PP) No. 68/1998 tentang Kawasan Suaka Alam dan Kawasan Pelestarian Alam

Polunin, Nicholas V.C.; Halim, Matheus K.; \& Kvalvtgnaes, Knut. (1983). Bali Barat: An Indonesian Marine Protected Area and Its Resources. Biological Conservation, 25, 171-191.

Ribot, Jesse C. \& Peluso, Nancy Lee. (2003). A Theory of Access. Rural Sociology, 68 (2) pp. 153-181. 
Robinson, Alan; Polunin, Nicholas; Kvalvagnaes, Knut, \& Halim, Matheus. (1981). Progress in Creating a Marine Reserve System in Indonesia. Bulletin of Marine Science, 31(3): 774-785.

Satria, Arif. (2014). Editorial “Politik Pengelolaan Pesisir". Majalah Samudra Edisi 129 Th. XII Januari.

Sowman, Marle; Hauck, Maria; Sittert, Lance van, \& Sunde, Jackie. (2011). Marine Protected Area Management in South Africa: New Policies, Old Paradigms. Environmental Management, 47:573-583.

Taman Nasional Bali Barat. (2005). Pengembangan Pariwisata Alam di Taman Nasional Bali Barat. Bali: Taman Nasional Bali Barat.

Taman Nasional Bali Barat. (2005). Petunjuk Teknis Penanganan Terpadu Tindak Pidana Kehutanan dan Perairan TNBB. Bali: TNBB

Taman Nasional Bali Barat. (2012). Laporan Tahunan Kegiatan Penyidikan dan Perlindungan
Hutan 2011. Bali: Taman Nasional Bali Barat

Taman Nasional Bali Barat. (2013). Laporan Tahunan Kegiatan Penyidikan dan Perlindungan Hutan BTNBB 2012. Bali: Taman Nasional Bali Barat.

Undang-Undang No 5/1990 tentang Konservasi Sumber Daya Hayati dan Ekosistemnya.

Vandergeest, Peter. (1996). Mapping Nature: Territorialization of Forest Rights in Thailand. Society \& Natural Resources: An International Journal, 9:2, 159-175.

Vandergeest, Peter \& Peluso, Nancy Lee. (1995). Territorialization and State Power in Thailand. Theory and Society, 24:385-426.

Wang, Guangyu; Innes, John L.; Wu, Sara W.; Krzyzanowski, Judi; Yin, Yongyuan, Dai, Shuanyou; Zhang, Xiaopin \& Liu, Sihui,. (2012). National Park Development in China: Conservation or Commercialization?, Ambio, 41:247-261. 